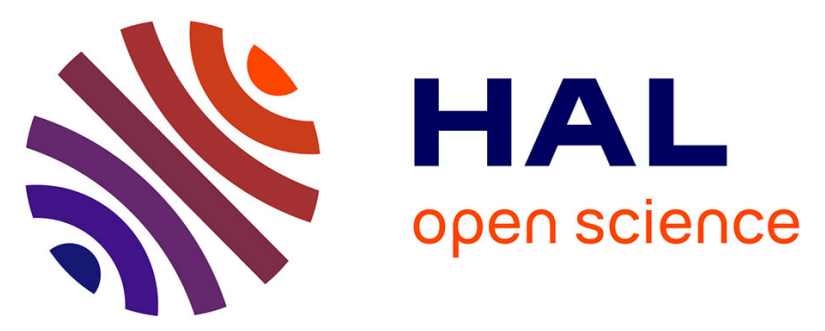

\title{
Development of Rectodispersible Tablets and Granulate Capsules for the Treatment of Serious Neonatal Sepsis in Developing Countries
}

Tina Kauss, Marie-Hélène Langlois, Alice Guyonnet-Dupérat, Thida Phoeung, Xiao Yu Xie, Anthony Cartwright, Nicholas White, Melba Gomes, Karen Gaudin

\section{To cite this version:}

Tina Kauss, Marie-Hélène Langlois, Alice Guyonnet-Dupérat, Thida Phoeung, Xiao Yu Xie, et al.. Development of Rectodispersible Tablets and Granulate Capsules for the Treatment of Serious Neonatal Sepsis in Developing Countries. Journal of Pharmaceutical Sciences - Elsevier, 2019, 108, pp.2805 - 2813. 10.1016/j.xphs.2019.03.004 . hal-03487215

\section{HAL Id: hal-03487215 \\ https://hal.science/hal-03487215}

Submitted on 20 Dec 2021

HAL is a multi-disciplinary open access archive for the deposit and dissemination of scientific research documents, whether they are published or not. The documents may come from teaching and research institutions in France or abroad, or from public or private research centers.
L'archive ouverte pluridisciplinaire HAL, est destinée au dépôt et à la diffusion de documents scientifiques de niveau recherche, publiés ou non, émanant des établissements d'enseignement et de recherche français ou étrangers, des laboratoires publics ou privés.

\section{(ㄷ)(1) $\$$}

Distributed under a Creative Commons Attribution - NonCommerciall 4.0 International 
Development of recto-dispersible tablets and granulate capsules for the treatment of serious neonatal sepsis in developing countries

\section{Authors}

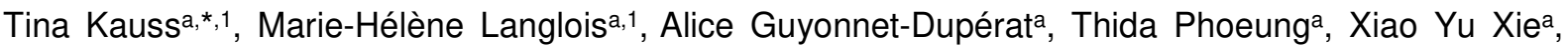
Anthony Cartwright ${ }^{\mathrm{b}}$, Nicholas White ${ }^{\mathrm{c}, \mathrm{d}}$, Melba Gomes ${ }^{\mathrm{e}}$, Karen Gaudina,1

a Univ. Bordeaux, EA 4575 Analytical and Pharmaceutical Developments Applied to Neglected Diseases and Counterfeits, Bordeaux, France

b Global Regulatory Solutions, Harpenden, UK

c Centre for Tropical Medicine, Nuffield Department of Medicine, University of Oxford, UK

d Faculty of Tropical Medicine, Mahidol University, Bangkok, Thailand

e Consultant, World Health Organization, Geneva, Switzerland

*Corresponding author: tina.kauss@u-bordeaux.fr; 146 rue Leo Saignat, 33076 Bordeaux, France, $2 \odot++33557571229$

1 Present address: ARNA, ChemBioPharm team, INSERM U1212, CNRS 5320, Univ. Bordeaux, Bordeaux, France 


\begin{abstract}
Current paediatric antibiotic therapies often use oral and parenteral routes of administration. Neither are suitable for treating very sick neonates who cannot take oral medication and may be several hours away from hospital in developing countries. Here, we report on the development of rectal forms of ceftriaxone, a third-generation cephalosporin, along with an absorption enhancer, sodium chenodeoxycholate. Recto-dispersible tablets and capsules were developed and successfully passed 6-month accelerated stability tests. Rabbit bioavailability showed plasma concentrations above the minimal inhibitory concentrations for 3 formulations of recto-dispersible tablets and 2 formulations of hard capsules. Clinical batches are currently being prepared for human evaluation with the prospect of offering therapeutic alternatives for treating critically ill neonates. This proof of concept for efficient rectal delivery of antibiotics could help the development of other rectal antibiotic treatments and increase options for non-invasive drug development for paediatric patients.
\end{abstract}

\title{
Main text
}

\section{Introduction}

Neonatal sepsis is an invasive bacterial infection. Neonates in developing countries are at particular risk of death with around 1 million deaths occurring within 24 hours of birth and another million within the first week of life ${ }^{1}$. Although the leading causes of death are pre-term births, events related to delivery, sepsis, meningitis and pneumonia together account for $21 \%$ of all newborn deaths ${ }^{2}$. Neonates that die in the first few days of life suffer from diseases and conditions that are associated with poor quality of care and reduced access to effective treatment ${ }^{2}$. Most deaths occur in or near home. Substantial reductions in deaths from neonatal infections can be achieved with prompt administration of effective injectable antibiotics ${ }^{3-5}$. However, simpler ways of administering antibiotic treatment reliably at home have recently been tested for children with no signs of severe sepsis ${ }^{6,7}$. These are more likely to succeed by reducing the number of injections, increasing access and adherence to treatment but their results cannot be extended to babies excluded from evaluation - low-birth weight infants or babies with signs of critical illness such as unconsciousness and convulsions; these children are at highest risk of 
death when the disease progresses rapidly. Evidence from previous trials indicates that between 10$76 \%$ of parents refuse referral in severe infections ${ }^{8-11}$. For most antibiotics, oral and injectable treatments are available, but neither can be used in the vicinity of patients who are too ill to take oral therapy and cannot reach hospital for several hours.

Ceftriaxone (CTX) is a semi-synthetic broad-spectrum third-generation cephalosporin antibiotic ${ }^{12}$. Its antibacterial spectrum covers both Gram-positive and Gram-negative bacteria. It has good Central Nervous System penetration ${ }^{13}$ and a good safety record ${ }^{14}$ which makes it suitable for antibiotic treatment of possible severe neonatal sepsis. The drug binds strongly to human serum proteins and hence the elimination half-life of CTX is age-dependent (15 to 19 hours in 1-8-day neonates compared to $8 \mathrm{~h}$ in adults), which favors its development and use as a single daily dose in critically ill neonates. CTX excretion is through urine and bile (40-60\% and $10-20 \%$ respectively) and does not change with dose ${ }^{15,16}$. The clinical efficacy of CTX is dependent upon the time during which free drug concentrations in serum remain above minimum inhibitory concentration (MIC, reportedly at or below $1 \mu \mathrm{g} / \mathrm{ml}$ for most sensitive bacteria ${ }^{17,18}$ ) and concentrations above the MIC are required for more than $50 \%$ of the dosing interval to be effective ${ }^{19}$.

CTX is highly hydrophilic and hydro-soluble, with a low octanol/water partition coefficient $(\log P=-2.1 \pm$ 0.2) ${ }^{20}$ and is thus poorly absorbed through mucosal membranes and categorized as class 3 in the Biopharmaceutics Classification System (BCS) ${ }^{21}$.

CTX has only been registered for use as an extemporaneously reconstituted injectable solution. It is sensitive to degradation in gastric fluid and is poorly absorbed from the intestinal tract ${ }^{12}$, which favors rectal compared to oral administration. However, CTX must be combined with an absorption enhancer to achieve adequate rectal absorption. A human bile salt, sodium chenodeoxycholate ( $\mathrm{NaCDC}$ ) in a ratio $1 / 4$ with CTX, has previously been shown as the optimal absorption enhancer for CTX ${ }^{22}$. Pre-formulation studies of CTX have been performed ${ }^{23}$ and these confirmed poor compatibility with most of liquid excipients but good compatibility with $\mathrm{NaCDC}$, thus supporting the development of solid drug dosage formulations ${ }^{23}$. 
Previous studies have suggested that rectal CTX therapy can achieve clinically relevant plasma concentrations in animals and man, and hence CTX was developed into rectal formulations that could be administered in the community to a neonate with a rapidly evolving serious sepsis infection, while awaiting transfer to hospital ${ }^{22}$. The formulations developed and tested by Hoffmann La Roche (Roche), the originator of CTX, was a wax suppository, which was not practical as a dosage form for tropical rural settings with high humidity and high day-time temperatures. Liquid dosage forms have been previously described, but these did not comply with standard requirements for further development ${ }^{24}$.

The aim of this study was to develop a stable and bioavailable solid CTX-NaCDC drug dosage form (recto-dispersible tablet or capsule), and compare bioavailability with the rectal wax suppository developed and tested by Roche. Solid dose medications currently on the market are tablets and capsules. Neither are commonly used for rectal administration, but some data on rectal use can be found in the literature. Rectal hard capsules are occasionally used in hospitals for pediatric patients when adjustment of the dose to the bodyweight is necessary but no commercialized form is yet available

25. Recto-dispersible tablets currently do not exist on the market, but a chewable lamotrigine dispersible tablet has shown significant absorption when administered rectally ${ }^{26}$. Therefore a first step was to develop the rationale for recto-dispersible mucoadhesive tablets based on the available literature and then develop rectal solid dosage forms of CTX with NaCDC as an absorption enhancer. Finally, in vitro and in vivo evaluation of the formulations are described. Success in this specific application of rectal antibiotic therapy as an alternative to oral or injectable treatments could have relevance for other antibiotics and medications for patients who can neither take oral medications nor access injectable treatment.

\section{Materials and Methods}

\section{Materials}

The active pharmaceutical ingredient used was Ceftriaxone hemiheptahydrate sodium salt from Discovery Fine Chemicals (batch $n^{\circ} 73777$ ). The excipients used were of pharmaceutical grade, as follows: Sodium chenodeoxycholate (NaCDC) from Biosynth, Switzerland (batch $n^{\circ}$ 0000011434); Emcompress (DP, Dicalcium phosphate) from Laboratoire Mendell, France (batch 88661/0); Pearlitol 400 and 100SD (Mannitol) from Roquette, France; Corn starch (CS) from Cooper, France; Lactose monohydrate $35 \mu \mathrm{m}$ and $75 \mu \mathrm{m}$ from Cooper, France; Hydroxypropylmethylcellulose E 50LV (HPMC) 
from Colorcon, USA; Polyvinylpyrrolidone (PVP K30) from Cooper, France; Maltodextrin from Cooper, France; Crospovidone (Kollidon CL, BASF, France); Croscarmellose sodium from Cooper, France ; Anhydrous colloidal silica (Aerosil 300, Cooper France); Magnesium stearate from Cooper, France; Talc from Cooper, France; Pregelatinized corn starch (starch derivative, Sepistab ST200) from Seppic, France; Microcrystalline cellulose (MCC, Avicel PH102) from Fagron, France; Magnesium Aluminometasilicate (Neusilin) from Fuji Chemical Industry, France.

The solvents used for analyses were of analytical grade. Water was deionized by osmosis, using "Système special dialyse Fernand Lopez, Toulouse, France" equipped with MILLERHOF 42250434 cartige.

\section{Methods}

\section{Granulation}

Where applicable, all powder blends (e.g. CTX and NaCDC +/- diluent, binder) were mixed in the Turbula powder mixer (10min, $34 \mathrm{rpm}$, Turbula T2F, France) prior to granulation. For wet granulation in a fluidized bed granulator (Miniglatt ${ }^{\circledR}$, Glatt Ingenieurtechnik $\mathrm{GmbH}$, Germany) with top down nozzle, the input air temperature was set at $70^{\circ} \mathrm{C}$, water spray pressure at 0.9 bar with a water flow rate around $4 \mathrm{~g} / \mathrm{min}$. Granules were dried at $70^{\circ} \mathrm{C}$ until complete dryness, with a powder temperature not exceeding $45^{\circ} \mathrm{C}$. For $130 \mathrm{~g}$ of powder, optimal conditions required $33 \mathrm{~g}$ of water and $6 \mathrm{~min}$ of drying, followed by 6 min of cooling before opening the apparatus.

When granulated "traditionally", the powder mixture of CTX, NaCDC and PVP K30 was moistened with water in a planetary mixer (Kitchenaid ${ }^{\circledR}$, France) and passed through a sieve (mesh $355 \mu \mathrm{m}$ ) for granulation. The granules were dried in an oven (Memmert UNE 200-800, Germany) for 24 hours at $40^{\circ} \mathrm{C}$.

The moisture content was measured using loss on drying (LOD) technique on $5 \mathrm{~g}$ of powder at $150^{\circ} \mathrm{C}$ for 15min (Mettler Toledo analyzer MJ33, France). The results were expressed as weight percentage. Granules with a LOD around 7\% were considered as dried, as some CTX levels of moisture (3.5 hydrate equivalent to approximately $9 \% \mathrm{w} / \mathrm{w}$ ) had been shown to be more labile ${ }^{23}$.

Alternatively, dry granulation was performed using a tablet press (Korsh Pressen Germany, $\left.\mathrm{n}^{\circ} \mathrm{K} 0000114,2002\right)$ with $14 \mathrm{~mm}$ flat round punches for CTX compaction. The tablets obtained were 
crushed with small mortar and pestle then passed through a sieve of $1.25 \mathrm{~mm}$. Granules could be further separated using sieves of 200 and $800 \mu \mathrm{m}$.

\section{Preparation of CTX recto-dispersible tablets}

The intra-granular phase was mixed with the excipients of the extra-granular phase using a Turbula powder mixer (10min, $34 \mathrm{rpm})$. This extra-granular phase included the bioadhesive (HPMC), the superdisintegrant (crospovidone), a flowability improver (silica/talc) and the lubricants (magnesium stearate and talc). The flowability of the final mixture was then characterized before being compressed according to European Pharmacopoeia standards.

The compression was performed on a laboratory scale tablet press (Korsh Pressen Germany, No. K0000114, 2002) using a set of flat round punches (diameter $14 \mathrm{~mm}$ ).

Tablets were sealed in alu/alu sealed blisters and stored at $4^{\circ} \mathrm{C}$ and evaluated for hardness, disintegration, friability and dissolution according to European Pharmacopoeia standards and analyzed using an HPLC method.

\section{Preparation of CTX capsules}

The CTX-NaCDC powder blend or the fluid bed granulated CTX-NaCDC granules were filled into hard shell capsules. The Capsules were sealed in alu/alu blisters and stored at $4^{\circ} \mathrm{C}$ for further analyses.

\section{Preparation of drug dosage forms for an animal study}

Tablets were prepared as described in the paragraph above. For the rabbit studies, the tablet mass was adjusted for rabbit weight by cutting the tablet to obtain one entire piece that was placed into a $1 \mathrm{~mL}$ syringe to maintain the tablets' integrity during storage and transport. Syringes containing tablets adjusted to each rabbits' bodyweight were sealed into alu/alu blisters and kept in a fridge until use. Capsules $n^{\circ} 4$ were manually filled with CTX and NaCDC powders of CTX-NaCDC granules to adjust the weight of their content to the bodyweight of each rabbit. They were stored in alu/alu blisters at $4^{\circ} \mathrm{C}$ and administered using a home-made blunt cut-edge syringe.

Suppositories were prepared with 20\% w/w CTX, 5\% NaCDC and 75\% Suppocire AML, as formulated by Roche and tested in humans ${ }^{22}$. Powders were dispersed using a magnetic stirrer at $40^{\circ} \mathrm{C}$ in melted Suppocire. 
Samples to be used in testing in rabbits were molded in a pre-weighted $1 \mathrm{~mL}$ syringe with a cut end. After solidification, the quantity was individually adjusted to each rabbit's bodyweight by cutting the excess weight of the suppository. Samples were then sealed in alu/alu blisters and kept in the fridge until use. All formulations were tested for batch homogeneity and content using HPLC method before use.

\section{Bulk and tapped density}

The bulk densities and tapped densities of the mixtures and granules were evaluated using a measuring cylinder placed on a tapping machine (Vankel Tap density, Varian, France) that subjected the mixture to a specified number of taps $(10,250$, etc). The different densities were obtained by direct reading of the volume of the mixture in the measuring cylinder after weighing a certain quantity of powder.

\section{Flowability}

The flowability of powders, mixtures and grains was evaluated through a $10 \mathrm{~mm}$ funnel in accordance to the flow test of the European pharmacopoeia (European Pharmacopoeia 9) using a PharmaTest PTGS4 (PharmaTest, France) apparatus. An exactly weighed quantity of powder was introduced in the funnel and the time of flow across the orifice was measured. The results are a mean of three replicates.

\section{Hardness}

Tablet hardness was measured using a European Pharmacopoeia hardness tester (PTB 311E, PharmaTest, France).

\section{Disintegration}

Tablet disintegration was measured according to the European Pharmacopoeia method using an Erweka ZT501 (France) apparatus. The tablet disintegration time was noted after their complete disintegration in $1 \mathrm{~L}$ distilled water at $37^{\circ} \mathrm{C}$.

\section{Dissolution}

Dissolution was measured using a paddle apparatus (AT7, Sotax, France), filled with $900 \mathrm{~mL} 50 \mathrm{mM}$ phosphate buffer at $\mathrm{pH} 7.5$ and at $37^{\circ} \mathrm{C}$. The stirring rate was set at $50 \mathrm{rpm}$. Samples were taken after 
filtration with $10 \mu \mathrm{m}$ prefilters at defined times and analyzed using the UV absorbance at $270 \mathrm{~nm}$. The content was derived from a $2-40 \mu \mathrm{g} / \mathrm{mL}$ linear standard curve $\left(R^{2}>0.998\right)$. Preliminary studies (not detailed here) showed the UV spectroscopic method was linear, reproducible and that up until $14 \mathrm{~h}$ no significant degradation of CTX had occurred (content was checked in parallel by the HPLC method).

\section{Stability evaluation}

Formulations were sealed after manufacture into Alu/Alu blisters and then tested in a climatic chamber at $40^{\circ} \mathrm{C} / 75 \%$ relative humidity $(\mathrm{RH})(\mathrm{ICH}$ accelerated aging conditions) or at local, uncontrolled atmospheric conditions (mean $21^{\circ} \mathrm{C}, 55-60 \% \mathrm{RH}$ ). The CTX content was analyzed at T0 (initial value at zero time) and after 1 month, 3 months and 6 months of accelerated aging using the HPLC method and compared to the CTX content obtained at T0. The results were expressed as $\%$ of the initial CTX content.

\section{HPLC analysis of CTX formulations}

The HPLC assay was carried out using an HPLC system (SpectraSystem, France) with a C18 reverse phase column (YMC ODS-H80 $150 \times 4.6 \mathrm{~mm}, 4 \mu \mathrm{m}$ ), a pump (P1000), an auto-sampler (AS3000), a DAD detector (UV6000), a degasser (Vacuum degasser, Biotech AB, France). The method with minor modifications had previously been validated and described ${ }^{27}$. Briefly, the method was based on ionpairing reverse phase liquid chromatography, the mobile phase was a combination of $18 \mathrm{mM}$ tetrabutylammonium bromide diluted in phosphate buffer and methanol $(70: 30, \mathrm{v} / \mathrm{v})$ and the buffer solution was composed of a mixture of $\mathrm{KH}_{2} \mathrm{PO}_{4} / \mathrm{K}_{2} \mathrm{HPO}_{4}$ at $25 \mathrm{mM}$, $\mathrm{pH}$ 7.5. This buffer was also used for sample preparation and dilutions. The volume of injection was $10 \mu \mathrm{L}$.

\section{Animal CTX bioavailability assessment and analysis}

Bioavailability in rabbits was carried out at the DETERCA animal facility laboratory of the Bordeaux University (animal facility agreement $n^{\circ}$ A33-0.63-235, animal experiment authorization and ethical committee agreement DIR 13123).

Six white New Zealand healthy male adult rabbits (Eurolap, France) were used per group of rectally delivered CTX solid formulations and compared with the CTX rectal wax suppository control group and the reference group of intravenous CTX. Animals were housed individually and provided with standardized rabbit pellets and water ad libitum. Animals were weighed and restrained the day before 
the treatment. All formulations were dosed and individually adjusted at $20 \mathrm{mg} / \mathrm{kg}$ of body weight. Administration was preceded by rectum emptying using an inflatable balloon. The IV control formulation was administered using a catheter in the left ear as a one-minute injection. Blood samples were withdrawn into $4 \mathrm{~mL}$ lithium heparinized tubes at predefined times (t0, $5 \mathrm{~min}, 15 \mathrm{~min}, 30 \mathrm{~min}, 45 \mathrm{~min}, 1 \mathrm{~h}$, $2 \mathrm{~h}, 4 \mathrm{~h}, 8 \mathrm{~h}$ and $24 \mathrm{~h}$ ) using a $24 \mathrm{G}$ catheter in the right ear. Samples were centrifuged immediately at $2500 \mathrm{rpm}$ for $10 \mathrm{~min}$. Plasma was frozen immediately at $-20^{\circ} \mathrm{C}$ and plasma concentration was determined by HPLC method. ${ }^{22}$ Bioavailability was calculated from individual plasma profiles using trapezoidal rule. After the treatment, rabbits were either kept as pets by individual volunteers or by the White Rabbit Association, or sacrificed by a lethal injection of sodium pentobarbital after an injection of a sedative $\left(\right.$ Calmivet $\left.^{\circledR}\right)$.

\section{Statistical analysis}

Statistical analyses were performed using Excel Student test. Differences were considered significant at a threshold level of $p<0.05$.

\section{Results and Discussion}

\section{Rationale for recto-dispersible tablets}

Our target product profile (TPP) was stable solid drug dosage forms, recto-dispersible tables or capsules, exhibiting adequate bioavailability and short Tmax, which would enable prompt treatment of probable serious neonatal sepsis in high burden developing countries, where hospital treatment is often refused or difficult. Rectal CTX would facilitate immediate administration and be stable in tropical conditions. A single $500 \mathrm{mg}$ dose was evaluated, but further dose to weight adjustments may be required at a later date. A rectal treatment would have all the advantages in terms of stability and ease of administration, but achieve rapid drug release, comparable with traditional fatty suppositories which are not practical because they would melt in tropical conditions.

Our development was based on existing oro-dispersible formulations. To avoid premature expulsion, mucoadhesive agents commonly used in vaginal ${ }^{28,29}$ or sublingual ${ }^{30,31}$ tablets were evaluated. The most commonly used mucoadhesive polymers 32 form a hydrophilic matrix and provide sustained release of the active pharmaceutical ingredient (API) which can be counterbalanced with a super- 
disintegrant. We examined excipients such as piroxicam ${ }^{30,31}$, carvediol ${ }^{33}$ and fentanyl ${ }^{34}$ which allow optimal exposure of the API (and bioadhesive retention), dicalcium phosphate and mannitol as fillers (mannitol also has bioadhesive properties with high dissolution), crospovidone, sodium croscarmellose or starch glycocholate as disintegrants with bioadhesive properties, magnesium stearate (as lubricant) for formulating mucoadhesive super-disintegrant tablets ${ }^{30,31,33,34}$. These studies concerned BCS 2 class APIs and we found no formulation developed associating an absorption enhancer (commonly considered as necessary for oral administration of BCS $3 \mathrm{API}$ ), with both a mucoadhesive and a superdisintegrant. Direct compression of oral or buccal mucoadhesive tablets is reported using carbomer or HPMC as mucoadhesive excipients ${ }^{35-37}$. The bile salt derivative, sodium glycodeoxycholate used as absorption enhancer did not negatively affect the tablet adhesiveness which made it acceptable for a buccal bioadhesive drug delivery system ${ }^{37}$.

Pre-formulation studies ${ }^{23}$ pointed to some key constraints: poor flowability and moisture lability. Therefore, direct compression or dry granulation, which do not require wetting the powder blend, appeared essential to prevent water induced instability. Our formulation was intended for the rectal route and an important consideration was the limited quantity of fluid available in the rectum for disintegration and dissolution of CTX ${ }^{38}$. Therefore, hydrophilic and water attracting excipients were of special interest. Furthermore, introducing a solid form in the rectum can activate the defecation reflex in the baby. The size of the solid form therefore needed to be as small as possible.

In view of the required properties for dispersible (oral) tablets and the rectal route for systemic administration, we considered the following tablet compositions as a starting point for further development of recto-dispersible tablets:

- $\quad 500 \mathrm{mg}$ CTX as the active pharmaceutical ingredient

- $\quad 125 \mathrm{mg} \mathrm{NaCDC}$ as an absorption enhancer, as previously published 22

- A mucoadhesive agent to avoid early leakage from rectum

- A super-disintegrant to help disintegration in the small quantity of liquid available in the rectal lumen

The balance between the mucoadhesive agent and disintegrant would need to allow complete and rapid drug release while conferring some mucoadhesive properties to the disintegrated granules. 
- Lubricants and glidants

- Filler

For better local tolerance the total weight of the tablet containing $500 \mathrm{mg}$ was limited to $1 \mathrm{~g}$.

\section{Design and in vitro evaluation of recto-dispersible tablets and capsules of CTX}

Direct compression was evaluated with various proportions of glidants (colloidal silica, talc, starch, or a mixture of them), direct compression fillers (model excipient used was dicalcium phosphate) and a mixture of these excipients. These did not improve flowability of CTX or the CTX-NaCDC mixture which was infinite according to European Pharmacopoeia standards. Dry and wet granulation were evaluated to solve flowability problems provided that drying was carried out rapidly after wetting and that moderate compression forces were used ${ }^{23}$. Wet granulation provided optimal results if precise control and a short CTX wetting time was used; to limit crystal damage a moderate compression using $80 \mathrm{MPa}$ obviated the significant PXRD broadening, which was seen with $150 \mathrm{MPa}$ compression ${ }^{23}$.

Granulation of CTX alone or a CTX-NaCDC blend was tested using fluid bed technology, traditional wet granulation technology (blender and oscillating granulator) or dry granulation (compaction, crushing, calibration) with PVP K30 as model binder. A limit of $2 \% \mathrm{w} / \mathrm{w}$ of PVP could be used by fluid bed technology for technical reasons. The results are summarized in Table 1.

Dry granulation was a viable alternative to wet granulation provided that moderate compression forces were used. The granule densification was greater compared to fluid bed granulation, but the yield was lower with our equipment $(<70 \%$ compared to wet granulation with $>85 \%)$ and the specific dry formulation equipment is required. 5\% PVP traditional granulation increased the density of granules compared to fluid bed granulation with $2 \%$ PVP, but the flowability was impaired. The flowability and bulk density were comparable in formulations with $2 \%$ PVP prepared using fluid bed and traditional granulation respectively. Fluid bed wet granulation was therefore considered as a means to control technical parameters and reduce wetting time of CTX, providing better long-term stability.

For tablet manufacture, lubricants and glidants were used in the usual proportions $(0.6 \%$ of talc, magnesium stearate and colloidal silica mixture in 1/1/1 ratio) to avoid technical problems (such as tablet capping) during compression even if the preliminary studies on granules did not show any significant 
reduction of flowability (data not shown). The required mucoadhesive properties were obtained by using HPMC.

The ratio between disintegrant and mucoadhesive was optimized to obtain a visible gel layer and adherent properties to the disintegration disk whilst showing the fastest disintegration time. A range of HPMC contents from 2 to $12 \%$ was evaluated, with disintegrant ranging from 2 to 7 percent. The combination of $2 \% \mathrm{HPMC}$ and $7 \%$ disintegrant gave the fastest disintegration time while still providing adherence properties to the disintegration disks. Binders and fillers were further screened in tablet formulation. Table 2 summarizes the optimization of the extra-granular and the intra-granular phases of recto-dispersible tablets and the results obtained.

HPMC as a mucoadhesive excipient is often considered as mucoadhesive agent of choice ${ }^{39,40}$ and has recently shown higher mucoadhesiveness compared to other common mucoadhesive agents such as guar gum, chitosan or Eudragit ${ }^{\circledR}$ RS ${ }^{41}$. A $5 \%$ HPMC formulation of sublingual sumatriptan tablets enabled a complete release of API in less than 15 minutes, which was faster than polyox or Carbopol examined as alternative mucoadhesive agents in the same formulation ${ }^{42}$. Disintegration times, obtained using discs in the European Pharmacopoeian disintegration apparatus, were reportedly higher in mucoadhesive formulations due to adhesion of hydrated polymer gel to the disc ${ }^{42}$. This was likely to increase the in vivo residence time ${ }^{34}$. As higher disintegration times made it easier to distinguish between formulations, we used this method to screen formulations.

The drug release for all fillers with tested formulations was very rapid (more than $85 \%$ in less than 15 minutes) and thus considered as similar according to current guidelines ${ }^{43}$. Dissolution was not a discriminant parameter for selecting an optimized formulation, but technical considerations and stability appeared to be of importance.

In view of these first results, PVP K30 was retained as a binder (but free flowing granules could be obtained without binder, cf. Table 1) and calcium phosphate, MCC and mannitol were kept as fillers for further characterization and pre-stability evaluation. Optimization concerned the granulation and compression parameters and when CTX and NaCDC were granulated with water only (without binder), filler was added in the extra-granular phase. The optimum drying conditions were assessed using LOD and was considered complete when $7-8 \%$ of water was recovered (corresponding to the part of crystalline water of CTX left after drying ${ }^{23}$ ). Approximately $33 \mathrm{~g}$ of water was necessary for granulation of $130 \mathrm{~g}$ of powder blend. 
The tablets were compressed using flat round punches, which are suboptimal for friability. Results are considered as preliminary because the shape would need further adaptation for rectal insertion (e.g. oblong) during industrial scale-up. Hardness was easily adjusted.

Dry granulated CTX and NaCDC were formulated into tablets (Table 3) and evaluated. Dicalcium phosphate and mannitol were screened as fillers in comparable formulations to wet granulation tablets. Mannitol in formulations posed difficulties for hardness adjustment. Low tablet hardness caused high friability. Longer disintegration times were obtained for dicalcium phosphate compared to mannitol (6.4 and 3 minutes respectively), as expected from the filler solubility and tablet hardness. Compared to wet granulation results, the disintegration time of mannitol dry granulation tablets was similar ( 3 minutes for both) and the preliminary stability results for mannitol and dicalcium phosphate were both satisfactory. Friability (including an appropriate tablet shape) needed further optimization.

The preliminary stability of the mannitol tablet with PVP and the dicalcium phosphate tablet with PVP achieved poor stability (preliminary stability $<75 \%$ after 6 months at $40^{\circ} \mathrm{C} / 75 \% \mathrm{RH}$ ) and were therefore discarded. The dicalcium phosphate optimized tablet (wet granulated, without PVP) did not comply with stability requirements and was discarded. The MCC tablet with and without PVP passed stability requirements, but tablet hardness would need to increase to avoid any friability problems. The results are summarized in Table 4.

Given these results, our final choice was fluid bed wet granulated CTX and NaCDC for reasons of higher yield, easier technical feasibility and controlled process parameters with our laboratory equipment. Three formulations of wet granulated recto-dispersible tablets were finally chosen, using CTX and $\mathrm{NaCDC}$ granulated using fluidized bed technology and water as the granulation solvent;

- Tablet containing mannitol as a filler, without binder

- Tablet containing MCC as a filler without binder

- Tablet containing MCC as a filler and PVP as a binder.

Capsules (CTX-NaCDC powder-filled and CTX-NaCDC fluid bed granulate-filled) were developed as alternative formulations and their preliminary stability was assessed (Table 4). Due to the poor flowability of CTX powder, powder-filled capsules were not considered as potential alternatives for commercial 
manufacture, except as a pharmacokinetic control for other formulations. Gelatin capsules were used or all hard shell capsules, as faster disintegration time is reported compared to hypromellose shells ${ }^{44}$. Granules filled in capsules were obtained without any binder, using water as the wetting solvent with fluidized bed technology.

\section{In vivo evaluation of CTX recto-dispersible tablets compared to capsules}

The 5 chosen formulations, 3 recto-dispersible tablets and 2 capsules, were tested in rabbits for bioavailability against the IV reference and fatty-wax suppository controls. Dosage was individually adjusted to the bodyweight of each rabbit to the equivalent of $20 \mathrm{mg} / \mathrm{kg} \mathrm{CTX}$ and administered rectally. Although the fatty-wax formulation did not comply with our TPP, Roche had previously shown that the product provided adequate bioavailability in humans ${ }^{22}$. The pharmacokinetic parameters are summarized in Table 5 and plasma profiles are given in Figure 1 (individual profiles Figure 1A and comparison of mean profiles Figure 1B).

For ethical reasons the number of animals used was limited, resulting in relatively high standard deviations. None of the differences in Cmax, AUC, time above MIC and absolute or relative bioavailability ( $F$ and F' respectively) between the Roche suppository control formulation and new rectal forms were statistically significant (Student test, $p>0.05$ ), although the capsule containing powder and tablet (MCC and PVP) appeared to reach higher bioavailability of CTX. The Tmax was significantly longer for both capsules ( $p<0.02$, Student test), but not for tablets. The MCC containing rectodispersible tablets were expelled by rabbits in some cases $(2 / 6$ and 3/6 for MCC tablet with and without PVP respectively), but this was not observed for the mannitol tablets or for capsules. One suppository (control formulation) was also expelled. This could be related to the very dry conditions of a specific rabbit's rectum and might not occur in humans. The MCC and PVP-containing tablets seemed to have optimal in vivo characteristics, but if expulsion is an important risk, the mannitol tablet could represent the best compromise for the formulation of recto-dispersible tablets. MCC and PVP-containing tablets showed a shoulder on the plasma profile, which might be attributed to enterohepatic recycling of CTX 45. Interestingly, this shoulder was less visible on the other PK profiles. The bioavailability of powder- 
filled and granulate-filled capsules were obtained. Both showed good plasma profiles for CTX, but the capsule filled with powder would not be of value in industrial scale-up because of poor flowability.

\section{Conclusion}

In conclusion, three recto-dispersible tablet formulations were successfully designed, characterized and gave good CTX plasma profiles. These results provide proof of concept that recto-dispersible tablets and granulate-filled capsules might be viable alternatives to common rectal drug dosage forms, with the advantages of stability and ease of manufacture. They could be used for noninvasive administration of ceftriaxone in conditions where very sick neonates with probable septicemia cannot access or refuse hospital referral. Alternatively, hard capsules filled with granules might be formulated, but it is likely that this will increase capsule size and reduce bioavailability. Clinical batches of the formulations are currently being produced for human clinical trial evaluation.

Beyond this case example of ceftriaxone formulations, our study provides proof of concept for rectal medicines as an alternative to oral and injectable treatments.

\section{Acknowledgments}

This work was supported by the Grand Challenges, Canada [Saving Lives at Birth call, grant number \#0167-03].

The authors would like to gratefully acknowledge Oxford University, UK for financial and administrative management of the project. We also acknowledge the assistance of Hoffmann La Roche Inc, France, for ceftriaxone initial raw material and for access to their data, and to Gattefossé S.A.S, France, for providing free samples of their excipients.

M. Gomes is a former staff member of the World Health Organization (WHO); the authors alone are responsible for the views expressed in this publication and they do not necessarily represent the decisions, policy or views of the WHO.

\section{References}

1. United Nation Inter-Agency Group for Child Mortality Estimation. Levels \& Trends in Child Mortality: Report 2017, Estimates Developed by the UN Inter-Agency Group for Child Mortality 
Estimation.; 2017. doi:10.1148/radiology.144.1.7089246.

2. UNICEF. Every Child Alive: The urgent need to end newborn deaths | UNICEF Publications | UNICEF. Unicef. https://www.unicef.org/publications/index_102640.html. Published 2018. Accessed December 11, 2018.

3. Bang AT, Bang RA, Baitule SB, Reddy MH, Deshmukh MD. Effect of home-based neonatal care and management of sepsis on neonatal mortality: field trial in rural India. Lancet. 1999;354(9194):1955-1961.

4. Bang AT, Paul VK, Reddy HM, Baitule SB. Why do neonates die in rural Gadchiroli, India? (Part I): primary causes of death assigned by neonatologist based on prospectively observed records. J Perinatol. 2005;25 Suppl 1(Part I):S29-S34. doi:10.1038/sj.jp.7211269.

5. Bang AT, Reddy HM, Bang R a, Deshmukh MD. Why do neonates die in rural Gadchiroli, India? (Part II): estimating population attributable risks and contribution of multiple morbidities for identifying a strategy to prevent deaths. J Perinatol. 2005;25 Suppl 1(Part II):S35-S43. doi:10.1038/sj.jp.7211270.

6. Tshefu A, Lokangaka A, Ngaima S, et al. Simplified antibiotic regimens compared with injectable procaine benzylpenicillin plus gentamicin for treatment of neonates and young infants with clinical signs of possible serious bacterial infection when referral is not possible: a randomised, open-lab. Lancet. 2015;385(9979):1767-1776. doi:10.1016/S0140-6736(14)62284-4.

7. Mir F, Nisar I, Tikmani SS, et al. Simplified antibiotic regimens for treatment of clinical severe infection in the outpatient setting when referral is not possible for young infants in Pakistan (Simplified Antibiotic Therapy Trial [SATT]): a randomised, open-label, equivalence trial. Lancet Glob Heal. 2017;5(2):e177-e185. doi:10.1016/S2214-109X(16)30335-7.

8. Baqui $\mathrm{AH}$, El-Arifeen S, Darmstadt $\mathrm{GL}$, et al. Effect of community-based newborn-care intervention package implemented through two service-delivery strategies in Sylhet district, Bangladesh: a cluster-randomised controlled trial. Lancet. 2008;371(9628):1936-1944. doi:10.1016/S0140-6736(08)60835-1.

9. Zaidi AK, Tikmani SS, Warraich HJ, et al. Community-based treatment of serious bacterial infections in newborns and young infants: a randomized controlled trial assessing three antibiotic regimens. PediatrInfectDis J. 2012;31(1532-0987 (Electronic)):667-672.

10. Owais A, Sultana S, Stein AD, et al. Why do families of sick newborns accept hospital care? A 
community based cohort study in Karachi, Pakistan. J Perinatol. 2012;31(9):586-592. doi:10.1038/jp.2010.191.Why.

11. Wall SN, Mazzeo $\mathrm{Cl}$, Adejuyigbe EA, et al. Ensuring quality in AFRINEST and SATT: clinical standardization and monitoring. PediatrInfectDis J. 2013;32 Suppl 1(1532-0987 (Electronic)):S39-S45. doi:10.1097/INF.0b013e31829ff801.

12. Cho SW, Lee JS, Choi SH. Enhanced Oral Bioavailability of Poorly Absorbed Drugs. I. Screening of Absorption Carrier for the Ceftriaxone Complex. J Pharm Sci. 2004;93(3):612-620. doi:10.1002/jps.10563.

13. Steele RW, Eyre LB, Bradsher RW, Weinfeld RE, Patel IH, Spicehandler J. Pharmacokinetics of Ceftriaxone in Pediatric Patients With Meningitis. Antimicrob Agents Chemother. 1983;23(2):191-194

14. Mulhall A, Louvois $\mathrm{J}$ De, James J. Pharmacokinetics and safety of ceflriaxone in the neonate. Eur J Pediatr. 1985;144:379-382.

15. Stoeckel K, Mcnamara PJ, Brandt R, Plozza-nottebrock H, Ziegler WH. Effects of concentrationdependent plasma protein binding on ceftriaxone kinetics. Clin Pharmacol Ther. 1981;29(5):650657.

16. Theriaque. Theriaque, french public medical database. www.theriaque.org. Published 2018. Accessed July 23, 2018.

17. European Committee on Antimicrobial Susceptibility. Testing Breakpoint Tables for Interpretation of MICs and Zone Diameters European Committee on Antimicrobial Susceptibility Testing Breakpoint Tables for Interpretation of MICs and Zone Diameters. Vol v8.1, vali.; 2018. http://www.eucast.org/fileadmin/src/media/PDFs/EUCAST_files/Breakpoint_tables/v_8.1_Break point_Tables.pdf.

18. Theriaque. Ceftriaxone. theriaque.org. Published 2018.

19. Downes KJ, Hahn A, Wiles J, Courter JD, Vinks AA. Dose optimisation of antibiotics in children: application of pharmacokinetics/pharmacodynamics in paediatrics. Int $J$ Antimicrob Agents. 2014;43(3):223-230. doi:10.1016/j.jiantimicag.2013.11.006.

20. Lee S, Kim SK, Lee DY, et al. Cationic analog of deoxycholate as an oral delivery carrier for ceftriaxone. J Pharm Sci. 2005;94(11):2541-2548. doi:10.1002/jps.20478.

21. Dressmann J, Wolfgang J. PROPOSAL TO WAIVE IN VIVO BIOEQUIVALENCE 
REQUIREMENTS FOR THE WHO MODEL LIST OF ESSENTIAL MEDICINES Proposal to waive in vivo bioequivalence requirements for the WHO Model List of Essential Medicines immediate release, solid ora. World Heal Organ. 2005;QAS/04.109:1-45.

22. Ba B, Gaudin K, Désiré A, et al. Ceftriaxone Absorption Enhancement for Noninvasive Administration as an Alternative to Injectable Solutions. Antimicrob Agents Chemother. 2018;62(12):e01170-18. doi:10.1128/AAC.01170-18.

23. Kauss $\mathrm{T}$, Marchivie M, Phoeung $\mathrm{T}$, et al. Preformulation studies of ceftriaxone for pediatric nonparenteral administration as an alternative to existing injectable formulations. Eur J Pharm Sci. 2017;104(October 2016):382-392. doi:10.1016/j.ejps.2017.04.010.

24. Kauss T, Gaubert A, Tabaran L, et al. Development of rectal self-emulsifying suspension of a moisture-labile water-soluble drug. Int $J$ Pharm. 2017;536(1):283-291. doi:10.1016/j.jpharm.2017.11.067.

25. Leino J. The value of hard gelatin capsules as a rectal dosage form in man using ibuprofen and metoclopramide hydrochloride as model drugs. 2004.

26. Birnbaum AK, Ph D, Kriel RL, et al. Relative Bioavailability of Lamotrigine Chewable Dispersible Tablets Administered Rectally.

27. Gaudin K, Langlois M, Kauss T, et al. In Vitro Ceftriaxone Stability at New-borns ' Rectal PH Assessed by UV and HPLC Methods. Pharm Anal Acta. 2015;6(7). doi:10.4172/21532435.1000393.

28. Sánchez MT, Ruiz MA, Castán H, Morales ME. A novel double-layer mucoadhesive tablet containing probiotic strain for vaginal administration: Design, development and technological evaluation. Eur J Pharm Sci. 2018;112:63-70. doi:10.1016/J.EJPS.2017.11.006.

29. Hassan AS, Soliman GM, Ali MF, El-Mahdy MM, El-Gindy GE-DA. Mucoadhesive tablets for the vaginal delivery of progesterone: in vitro evaluation and pharmacokinetics/pharmacodynamics in female rabbits. Drug Dev Ind Pharm. October 2017:1-9. doi:10.1080/03639045.2017.1386203.

30. Kate VK, Payghan SA. Development of Directly Compressible Mucoadehsive Fast Disintegrating Sublingual Tablet System of Piroxicam Using 3 factor , 3 Level Box Behnken Design. Asian J Biomed Pharm Sci. 2014;03(27):19-29.

31. Payghan SA, Kate VK. Physicochemical Evaluation of Mannitol Based Mucoadhesive Fast Disintegrating Tablet for Rapid Absorption of Piroxicam. 2013;3:1-15. 
32. Acartürk F. Mucoadhesive vaginal drug delivery systems. Recent Pat Drug Deliv Formul. 2009;3(3):193-205. http://www.ncbi.nlm.nih.gov/pubmed/19925443. Accessed December 15, 2017.

33. Adepu L, Kotikalapudi LS, Yerraguntla SR. Design and Evaluation of Mucoadhesive Fast Disintegrating Sublingual Tablets Containing Poorly Soluble Drug for Enhancement of Oral Bioavailability. Am J Pharmatech Res. 2013;3(February):2249-3387.

34. Bredenberg S, Duberg M, Lennernäs B, et al. In vitro and in vivo evaluation of a new sublingual tablet system for rapid oromucosal absorption using fentanyl citrate as the active substance. Eur J Pharm Sci. 2003;20(3):327-334. doi:10.1016/j.ejps.2003.07.002.

35. Dias R, Sakhare S, Mali K. In-vitro absorption studies of mucoadhesive tablets of acyclovir. Indian J Pharm Educ Res. 2010;44(2):183-188.

36. Venkatesan N, Yoshimitsu J, Ohashi Y, et al. Pharmacokinetic and pharmacodynamic studies following oral administration of erythropoietin mucoadhesive tablets to beagle dogs. Int J Pharm. 2006;310(1-2):46-52. doi:10.1016/j.jpharm.2005.11.014.

37. Senel S, Duchêne D, Hincal AA, Capan Y, Ponchel G. In vitro studies on enhancing effect of sodium glycocholate on transbuccal permeation of morphine hydrochloride. $J$ Control Release. 1998;51(2-3):107-113. http://www.ncbi.nlm.nih.gov/pubmed/9685907. Accessed December 15, 2017.

38. Allen JL V. Suppositories, First Edition. Pharmaceutical Press, Grayslake, USA; 2008.

39. Boddupalli BM, Mohammed ZNK, Nath RA, Banji D. Mucoadhesive drug delivery system: An overview. J Adv Pharm Technol Res. 2010;1(4):381-387. doi:10.4103/0110-5558.76436.

40. Gilhotra RM, Ikram M, Srivastava S, Gilhotra N. A clinical perspective on mucoadhesive buccal drug delivery systems. J Biomed Res. 2014;28(2):81-97. doi:10.7555/JBR.27.20120136.

41. Notario-Pérez F, Martin-Illana A, Cazorla-Luna R, et al. Influence of Chitosan Swelling Behaviour on Controlled Release of Tenofovir from Mucoadhesive Vaginal Systems for Prevention of Sexual Transmission of HIV. Mar Drugs. 2017;15(2):1-16. doi:10.3390/md15020050.

42. Tayel SA, El Nabarawi MA, Amin MM, AbouGhaly MHH. Comparative Study Between Different Ready-Made Orally Disintegrating Platforms for the Formulation of Sumatriptan Succinate Sublingual Tablets. AAPS PharmSciTech. 2016;66(6). doi:10.1208/s12249-016-0517-z.

43. European Medicines Agency. Guideline on the Investigation of Bioequivalence. Vol 1.; 2010. 
doi:CPMP/EWP/QWP/1401/98.

44. Missaghi S, Fassihi R. Evaluation and comparison of physicomechanical characteristics of gelatin and hypromellose capsules. Drug Dev Ind Pharm. 2008;32(7):829-838. doi:10.1080/03639040600608888.

45. Roberts MS, Magnusson BM, Burczynski FJ, Weiss M. Enterohepatic circulation: physiological, pharmacokinetic and clinical implications. Clin Pharmacokinet. 2002;41(10):751-790. doi:10.2165/00003088-200241100-00005.

\section{Figures' legends :}

Figure 1: (A) Individual rabbit plasma profiles per formulation administered rectally; (B) Mean rabbit plasma profiles of CTX rectal formulations in rabbits (truncated $X$ axis between $8 \mathrm{~h}$ and $24 \mathrm{~h}$ ). 
Plasma profiles of rabbits after administration of ceftriaxone

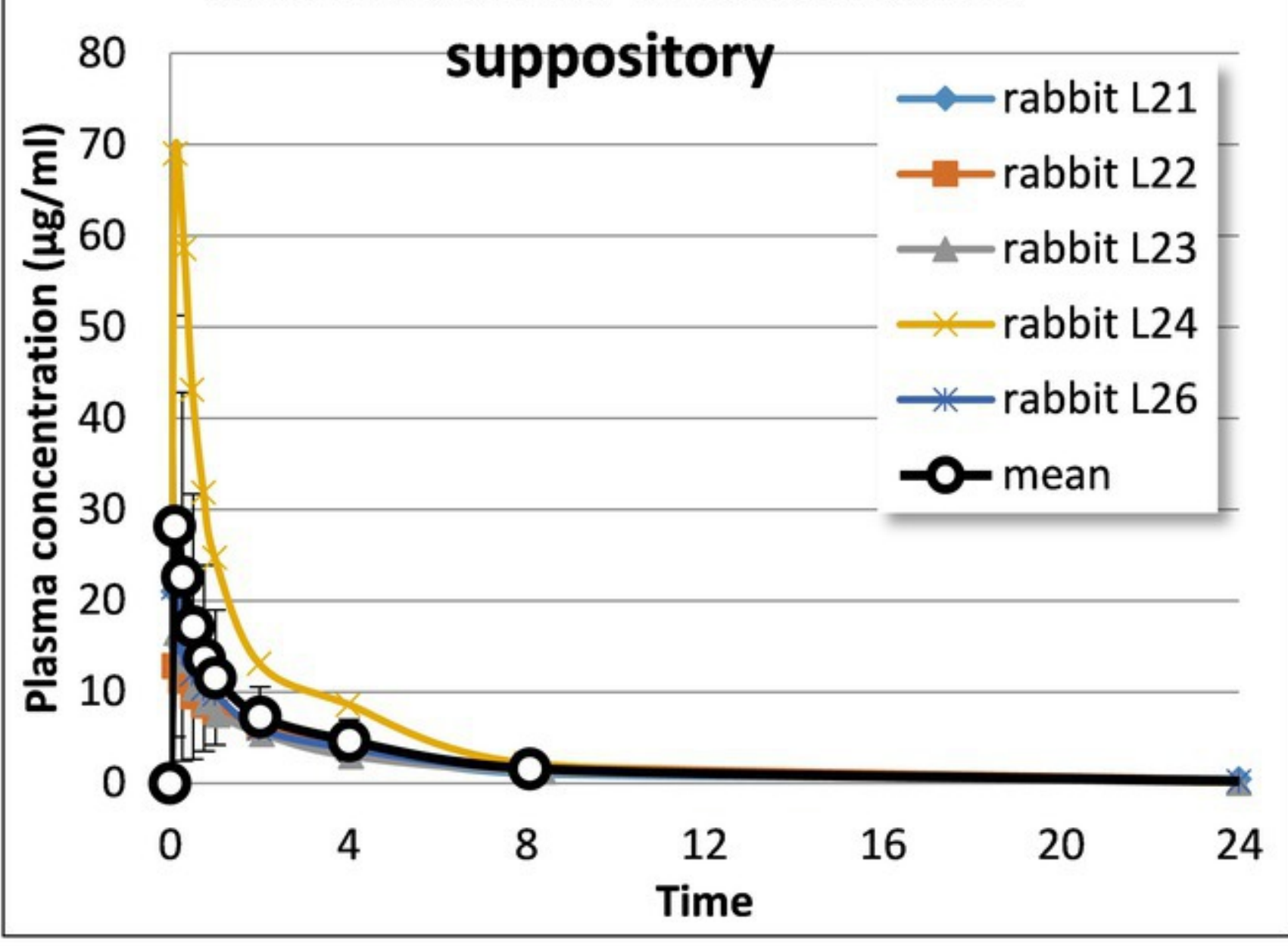

Plasma profiles of rabbits after administration of ceftriaxone Avicel

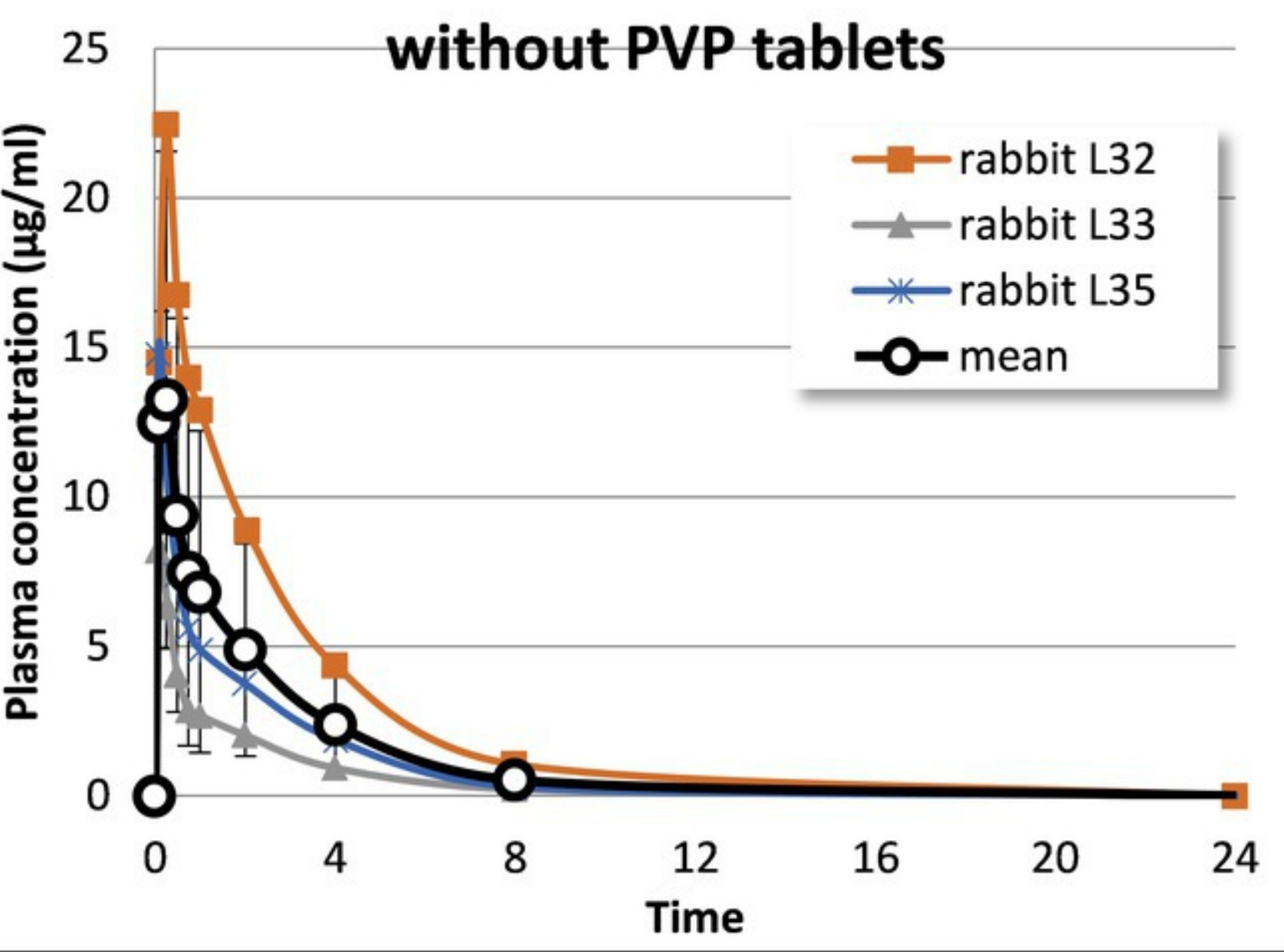

profiles of rabbits after administration of ceftriaxone
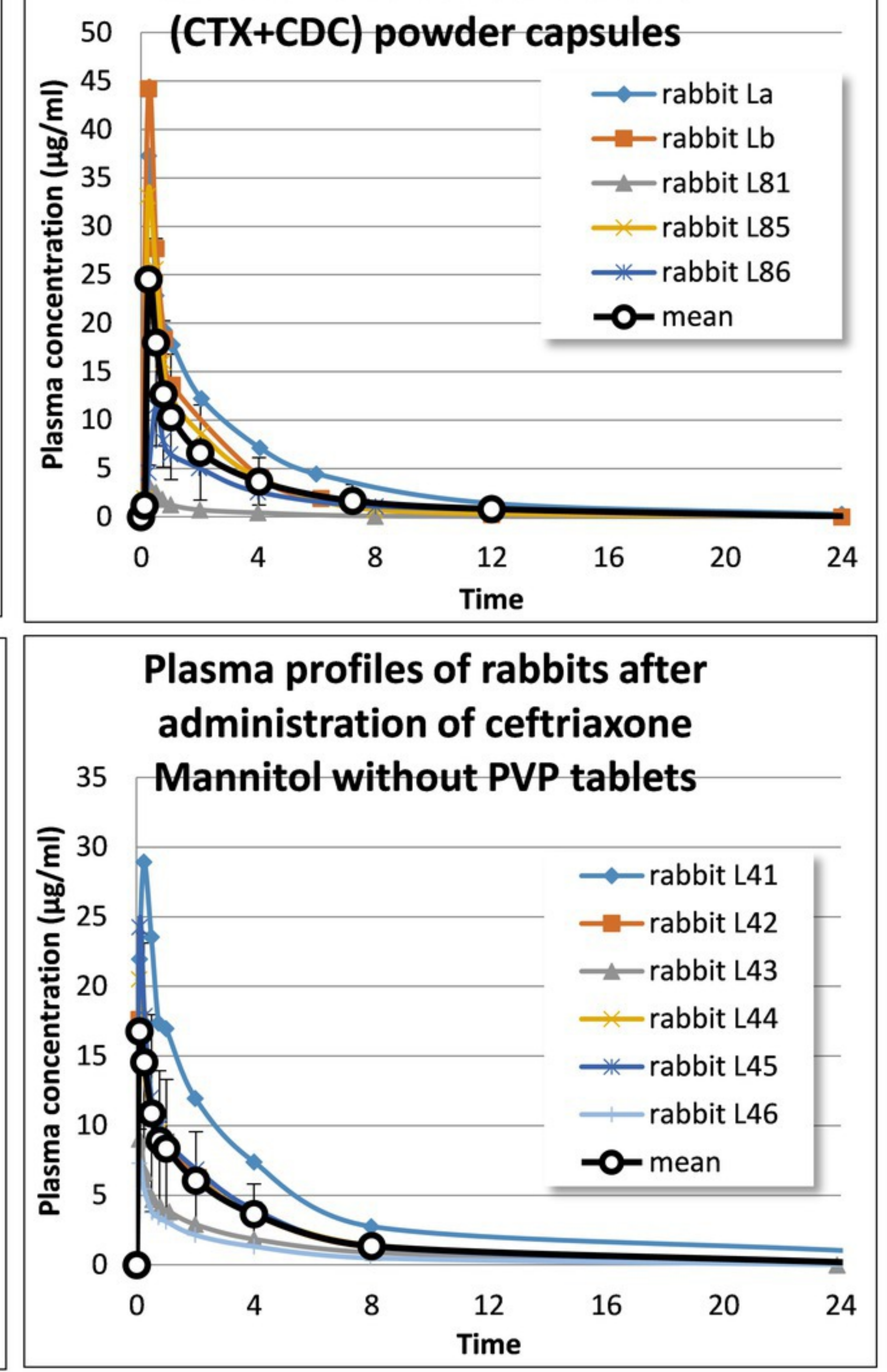

Plasma profiles of rabbits after administration of ceftriaxone
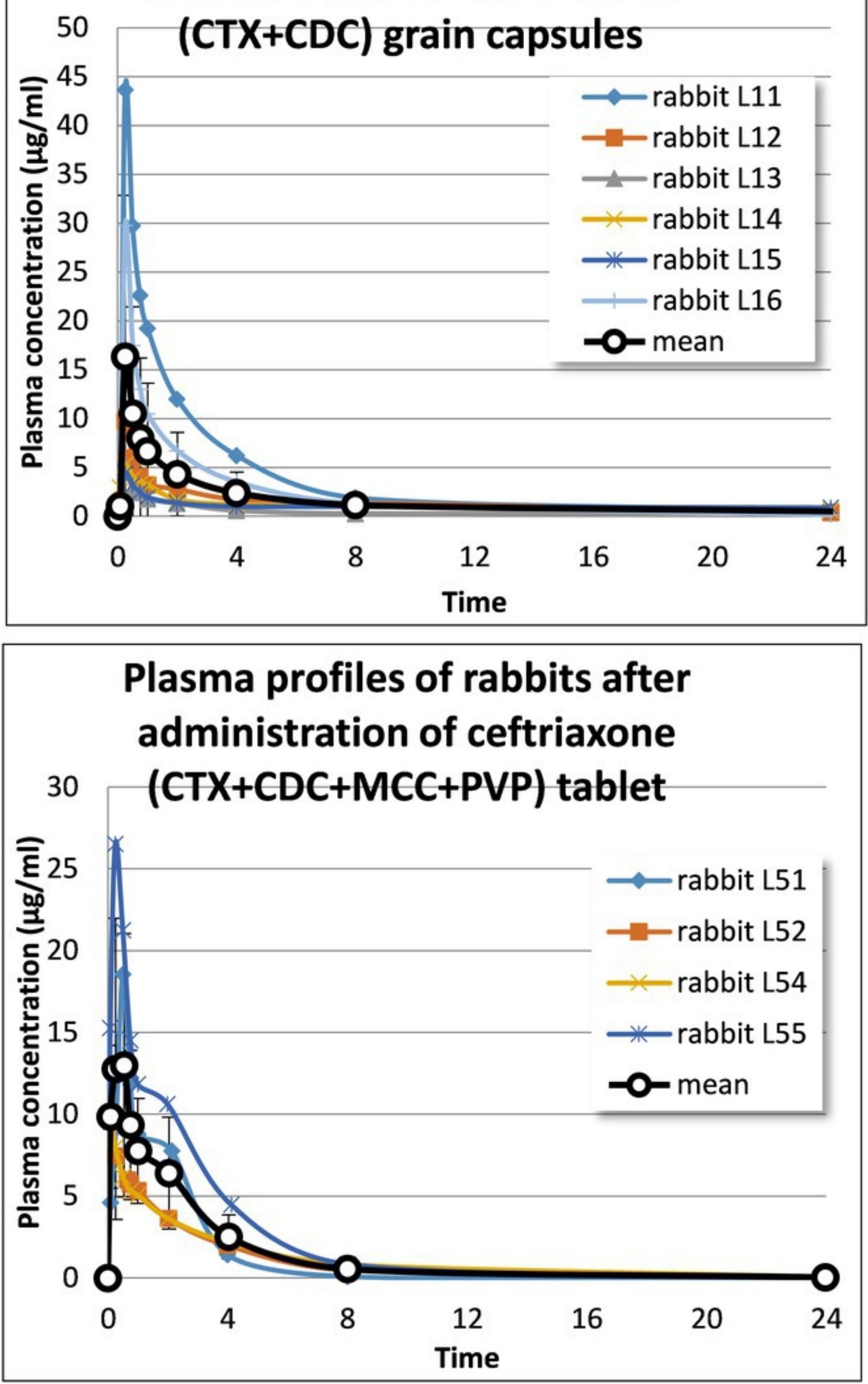
Mean plasma profiles of ceftriaxone formulations in rabbits




Table 1 : Granulation tests and preliminary stability assessment ( 6 months at $\left.40^{\circ} \mathrm{C} / 75 \% \mathrm{RH}\right)$ of granules compressed into tablets

\begin{tabular}{|c|c|c|c|c|}
\hline $\begin{array}{l}\text { Granulation } \\
\text { technique }\end{array}$ & $\begin{array}{l}\text { Composition } \\
\text { of granules }\end{array}$ & Flowability (s) & $\begin{array}{l}\text { Bulk /Tapped } \\
\text { D250 density } \\
(\mathrm{mg} / \mathrm{ml})\end{array}$ & $\begin{array}{l}\text { CTX Assay after } 6 \\
\text { months at } 40^{\circ} \mathrm{C} / 75 \% \mathrm{RH} \\
(\% \text { of } \mathrm{TO})\end{array}$ \\
\hline \multirow{4}{*}{$\begin{array}{l}\text { fluidized bed } \\
\text { granulation }\end{array}$} & CTX pure & 21 & $0.47 / 0.53$ & NA (99.2\% after 1 month) \\
\hline & CTX+PVP $1 \%$ & 40 & $0.42 / 0.63$ & 101.7 \\
\hline & $\mathrm{CTX}+\mathrm{NaCDC}$ & 26 & $0.43 / 0.49$ & 99.4 \\
\hline & $\begin{array}{l}\mathrm{CTX}+\mathrm{NaCDC} \\
+2 \% \mathrm{PVP}\end{array}$ & 17 & $0.42 / 0.55$ & 102.6 \\
\hline \multirow[t]{4}{*}{$\begin{array}{l}\text { traditional } \\
\text { granulation }\end{array}$} & $\begin{array}{l}\text { CTX+NaCDC } \\
+2 \% \text { PVP }\end{array}$ & 18 & $0.43 / 0.45$ & 93.7 \\
\hline & $\begin{array}{l}\mathrm{CTX}+\mathrm{NaCDC} \\
+5 \% \mathrm{PVP}\end{array}$ & 32 & $0.54 / 0.59$ & 91.0 \\
\hline & $\begin{array}{l}\text { CTX+NaCDC } \\
+7 \% \text { PVP }\end{array}$ & 16 & $0.49 / 0.54$ & 96.0 \\
\hline & $\begin{array}{l}\text { CTX+NaCDC } \\
+10 \% \text { PVP }\end{array}$ & 17 & $0.49 / 0.51$ & 92.9 \\
\hline \multirow{2}{*}{$\begin{array}{l}\text { dry } \\
\text { granulation }\end{array}$} & CTX & 16 & NA & 100.8 \\
\hline & $\mathrm{CTX}+\mathrm{NaCDC}$ & 16 & $0.62 / 0.64$ & 90.0 \\
\hline
\end{tabular}

NA : not available 
Table 2 : Optimization of intra-granular and extra-granular phases of recto-dispersible tablet formulation

\begin{tabular}{|c|c|c|c|c|c|c|c|c|c|c|c|c|c|c|c|}
\hline \multicolumn{16}{|c|}{ Intra-granular phase / quantity (mg) } \\
\hline Ceftriaxone & API & \multicolumn{7}{|l|}{500} & \multicolumn{7}{|l|}{500} \\
\hline $\mathrm{NaCDC}$ & $\begin{array}{l}\text { Absorption } \\
\text { Enhancer }\end{array}$ & \multicolumn{7}{|l|}{125} & \multicolumn{7}{|l|}{125} \\
\hline $\begin{array}{l}\text { Dicalcium } \\
\text { phosphate } \\
\text { (Emcompress) }\end{array}$ & \multirow[t]{5}{*}{ Fillers } & \multirow{2}{*}{\multicolumn{7}{|c|}{220}} & \multirow{2}{*}{\multicolumn{2}{|c|}{220}} & & & & & \\
\hline $\begin{array}{l}\text { MCC } \\
102)\end{array}$ (Avicel pH & & & & & & & & & & & & & & & \\
\hline Mannitol & & & & & & & & & & 220 & & & 220 & 220 & 220 \\
\hline Corn starch & & & & & & & & & & & 220 & & & & \\
\hline $\begin{array}{l}\text { Lactose } \\
\text { monohydrate }\end{array}$ & & & & & & & & & & & & 220 & & & \\
\hline $\begin{array}{l}\text { Pregelatinized corn } \\
\text { starch (Sepistab) }\end{array}$ & Binders & & & & & & & & & & & & 10 & & \\
\hline HPMC 50 & & & & & & & & & & & & & & 10 & \\
\hline PVP K30 & & 10 & & & & & & & 10 & 10 & 10 & 10 & & & \\
\hline Maltodextrin & & & & & & & & & & & & & & & 10 \\
\hline Extra-granular phase & / quantity (mg) & & & & & & & & & & & & & & \\
\hline HPMC 50 & Bioadhesive & 120 & 50 & 50 & 25 & 20 & 20 & 20 & 20 & & & & & & \\
\hline Croscarmellose & Super- & 30 & 30 & 50 & 50 & 50 & 70 & & & & & & & & \\
\hline Crospovidone & Disintegrants & & & & & & & 70 & 70 & & & & & & \\
\hline $\begin{array}{lc}\text { Aerosil } & / \mathrm{Mg} \\
\text { Stearate } & \text { TTalc } \\
(1 / 1 / 1) & \end{array}$ & $\begin{array}{l}\text { Glidants / } \\
\text { Lubricants }\end{array}$ & 18 & & & & & & & 18 & & & & & & \\
\hline Total (mg) & & 1023 & 953 & 973 & 948 & 943 & 963 & 963 & 963 & 963 & 963 & 963 & 963 & 963 & 963 \\
\hline $\begin{array}{l}\text { Flowability of the } \\
\text { grain (s) }\end{array}$ & & NA & NA & NA & NA & NA & NA & 16.5 & 26 & 16 & $\begin{array}{l}\text { infini } \\
\text { te }\end{array}$ & 24 & 20 & 18 & 17 \\
\hline $\begin{array}{l}\text { Disintegration of } \\
\text { tablet (min) }\end{array}$ & & 10 & 8 & 7 & 5 & 5 & 3 & 2 & 3 & 1.7 & 5 & 3 & 0.6 & 1.1 & 1.2 \\
\hline $\mathrm{TD}_{80}$ of tablet (min) & & NA & NA & NA & NA & NA & NA & 9.3 & 5 & 4 & 6.3 & 3.9 & 3.5 & 1.8 & 2.1 \\
\hline
\end{tabular}




\begin{tabular}{|c|c|c|c|c|c|c|c|c|c|c|c|c|c|c|}
\hline $\begin{array}{l}\text { Bad preliminary } \\
\text { stability indications* }\end{array}$ & NA & NA & NA & NA & NA & NA & & & & & $X$ & $X$ & & $X$ \\
\hline $\begin{array}{l}\text { Preliminary } \\
\text { conclusion }\end{array}$ & $X$ & $X$ & $X$ & $X$ & $X$ & $X$ & Go & Go & Go & $X$ & $\begin{array}{l}\text { X } \\
\text { Comp } \\
\text { ressio } \\
\mathrm{n} \\
\text { proble } \\
\mathrm{m}\end{array}$ & $X$ & $\begin{array}{l}\text { High } \\
\text { friab } \\
\text { ility } \\
(>3 \\
\%)\end{array}$ & $X$ \\
\hline
\end{tabular}

*browning of grain, HPLC demonstrated presence of degradation products. 
Table 3: Dry granulation formulations

\begin{tabular}{|c|c|c|}
\hline \multirow{2}{*}{$\begin{array}{l}\text { Composition (mg) } \\
\text { CTX }\end{array}$} & \multicolumn{2}{|c|}{$\begin{array}{l}\text { Dry granulation } \\
\text { TABLETS }\end{array}$} \\
\hline & 500 & 500 \\
\hline $\mathrm{NaCDC}$ & 125 & 125 \\
\hline Mannitol & - & 220 \\
\hline Dicalcium phosphate & 220 & - \\
\hline PVP K30 & 10 & 10 \\
\hline HPMC 50 & 20 & 20 \\
\hline Crospovidone & 70 & 70 \\
\hline Aerosil / Mg Stearate / Talc (1/1/1) & 18 & 18 \\
\hline \multicolumn{3}{|l|}{ Evaluation } \\
\hline Mass uniformity variation (\%) & $<5$ & $<5$ \\
\hline Friability $(\%)$ & 4.4 & $>50$ \\
\hline Hardness $(\mathrm{N})$ & 37.7 & 15.8 \\
\hline Disintegration (min) & 6.4 & 3.1 \\
\hline Stability $40^{\circ} \mathrm{C} / 75 \% \mathrm{RH}$ after 6 months / T0 (mean $\left.\pm \mathrm{SD}, \%\right)$ & 92.7 & 90.6 \\
\hline
\end{tabular}


Table 4 : Final CTX forms evaluation with powder or wet granulated CTX and NaCDC

\begin{tabular}{|c|c|c|c|c|c|c|}
\hline Composition (mg) & CAPSULES & & TABLETS & & & \\
\hline Formulation name & $\begin{array}{l}\text { Powder } \\
\text { filled } \\
\text { capsule }\end{array}$ & $\begin{array}{l}\text { Granulate } \\
\text { filled } \\
\text { capsule }\end{array}$ & $\begin{array}{l}\text { Mannitol } \\
\text { optimized } \\
\text { tablet }\end{array}$ & $\begin{array}{l}\text { MCC } \\
\text { optimized } \\
\text { tablet }\end{array}$ & $\begin{array}{l}\text { MCC+PVP } \\
\text { tablet }\end{array}$ & $\begin{array}{l}\text { Calcium } \\
\text { phosphate } \\
\text { optimized } \\
\text { tablet }\end{array}$ \\
\hline CTX & 500 & 500 & 500 & 500 & 500 & 500 \\
\hline $\mathrm{NaCDC}$ & 125 & 125 & 125 & 125 & 125 & 125 \\
\hline MCC & & & & 230 & 220 & \\
\hline Mannitol & & & 230 & & & \\
\hline Dicalcium phosphate & & & & & & 230 \\
\hline PVP K30 & & & & & 10 & \\
\hline HPMC 50 & & & 20 & 20 & 20 & 20 \\
\hline Crospovidone & & & 70 & 70 & 70 & 70 \\
\hline $\begin{array}{l}\text { Aerosil / Mg Stearate / } \\
\text { Talc (1/1/1) }\end{array}$ & & & 18 & 18 & 18 & 18 \\
\hline Evaluation & & & & & & \\
\hline Mass uniformity (\%) & $<5$ & $<5$ & $<5$ & $<5$ & $<5$ & $<5$ \\
\hline Friability (\%) & - & - & 2.12 & 1.15 & 3.20 & 1.03 \\
\hline Hardness (N) & - & - & 43 & 43 & 28 & 55 \\
\hline Disintegration (min) & NA & NA & 1.3 & 1.0 & 2.5 & 2.5 \\
\hline $\begin{array}{l}\text { Stability } 40^{\circ} \mathrm{C} / 75 \% \mathrm{RH} \\
\text { after } 6 \text { months / T0 } \\
\text { (mean } \pm \mathrm{SD}, \% \text { ) }\end{array}$ & $94.4 \pm 4.18$ & $97.7 \pm 1.47$ & $91.1 \pm 1.70$ & $93.9 \pm 0.51$ & $92.5 \pm 1.50$ & $77.2 \pm 14.40$ \\
\hline
\end{tabular}


Table 5 : Pharmacokinetic parameters of CTX rectal and IV formulations in rabbits

\begin{tabular}{|c|c|c|c|c|c|c|}
\hline $\begin{array}{l}\text { Ceftriaxone form } \\
(20 \mathrm{mg} / \mathrm{kg})\end{array}$ & $\begin{array}{l}C_{\max } \\
(\mu \mathrm{g} / \mathrm{ml})\end{array}$ & $\begin{array}{l}T_{\max } \\
(\min )\end{array}$ & $\begin{array}{l}\mathrm{T}(>\mathrm{MIC}) \\
(\mathrm{h})\end{array}$ & $\begin{array}{l}\text { AUC } C_{\infty, e x t} \\
\left(\mu g^{\star} h / m l\right)\end{array}$ & $\mathbf{F}(\%)$ & $F^{\prime}(\%)$ \\
\hline IV solution $(n=6)$ & $203 \pm 70$ & - & $11.2 \pm 4.2$ & $281 \pm 92$ & $100 \pm 33$ & - \\
\hline Suppository $(\mathrm{n}=5)$ & $28 \pm 23$ & $6 \pm 2$ & $4.4 \pm 1.4$ & $56 \pm 24$ & $20 \pm 8$ & $100 \pm 43$ \\
\hline $\begin{array}{l}\text { Capsule containing powder } \\
\text { blend }(n=5)\end{array}$ & $26 \pm 18$ & $18 \pm 7\left(^{*}\right)$ & $3.6 \pm 2.5$ & $47 \pm 33$ & $17 \pm 12$ & $85 \pm 59$ \\
\hline $\begin{array}{l}\text { Capsule containing } \\
\text { granulates }(n=6)\end{array}$ & $16 \pm 16$ & $15 \pm 0\left(^{*}\right)$ & $2.0 \pm 2.4$ & $27 \pm 31$ & $10 \pm 11$ & $49 \pm 55$ \\
\hline $\begin{array}{l}\text { Tablet containing MCC } \\
\text { and PVPK30 }(n=4)\end{array}$ & $16 \pm 8$ & $14 \pm 11$ & $2.7 \pm 1.4$ & $49 \pm 32$ & $17 \pm 11$ & $88 \pm 57$ \\
\hline $\begin{array}{l}\text { Tablet containing MCC } \\
\text { (but no binder) }(n=3)\end{array}$ & $15 \pm 7$ & $8 \pm 6$ & $2.2 \pm 2.0$ & $30 \pm 20$ & $11 \pm 7$ & $54 \pm 35$ \\
\hline $\begin{array}{l}\text { Tablet containing mannitol } \\
(\mathrm{n}=6)\end{array}$ & $18 \pm 8$ & $7 \pm 4$ & $3.3 \pm 2.3$ & $42 \pm 26$ & $15 \pm 9$ & $76 \pm 46$ \\
\hline
\end{tabular}

$\left({ }^{\star}\right)$ : significant difference of parameter compared to suppository (control) formulation (Student test, $p<0.05$ ) 